\title{
Three outstanding NOeG presentations: Morgenstern, Viner, and Menger on the laws of costs and returns
}

\section{Christian Gehrke ${ }^{1}$ (D)}

Published online: 30 April 2019

(c) The Author(s) 2019

\begin{abstract}
This paper re-examines three outstanding contributions on the laws of costs and returns that were first presented at $N O e G$ meetings in the interwar period. Oskar Morgenstern, in a paper presented in January 1930, provided a lucid account of the unresolved problems in the Marshallian approach to the construction of longrun industry supply curves. A few months later, Jacob Viner presented his classic paper on "Cost curves and supply curves". Viner's contribution, with its rigorous geometrical derivation of industry supply curves from the firms' cost situations in competitive conditions, became the model for innumerable textbook presentations of these issues, and a springboard for many further contributions. In another brilliant paper, first presented at a NOeG meeting in December 1935, Karl Menger severely criticized the axiomatic acceptance of the law of diminishing returns. Menger showed that the existing a priori "proofs" of this law are invalid, and made a strong plea for empirical verification. The present paper re-examines the three contributions, discusses their importance for the further development of partial equilibrium analysis, and suggests some reasons for their continuing relevance for present-day microeconomics.
\end{abstract}

Keywords Cost curves · Diminishing returns · Industry supply curves · Alfred Marshall

JEL Classification B21 · B31 · D24

\section{Introduction}

In the 1920s and 1930s, when the Nationalökonomische Gesellschaft (NOeG) was still an intimate debating club, consisting of a small circle of (predominantly Viennese) scholars interested in economic theory, a surprisingly large number of

Christian Gehrke

christian.gehrke@uni-graz.at

1 Department of Economics, University of Graz, Universitätsstr. 15/F4, 8010 Graz, Austria 
outstanding papers were presented at its meetings. One may recall papers by Ludwig Mises on socialist calculation, by Gottfried Haberler on international trade theory, by Adolf Löwe, Oskar Morgenstern, Friedrich Hayek and others on business cycle theory, or by Paul Rosenstein-Rodan, Karl Menger and Oskar Morgenstern on the role of time, uncertainty, and expectations (Klausinger 2016). In the present paper, I want to draw attention to three outstanding $N O e G$ presentations on the laws of costs and returns and the construction of long-run industry supply curves. In the early 1930s this was a topical theme because of the criticisms that the treatment of these issues by Alfred Marshall had drawn in the so-called "cost controversies" of the 1920s. These debates, which took place mainly in the pages of the Economic Journal, had been completely ignored in the German-language area until Oskar Morgenstern took up this issue in a long review article which he presented at two consecutive NOeG meetings in January and February 1930 (Morgenstern 1931). On Morgenstern's initiative, Jacob Viner then delivered his famous paper on "Cost curves and supply curves" at a further NOeG meeting in September 1930. Viner's seminal contribution, which Morgenstern managed to secure for the Zeitschrift für Nationalökonomie $(Z f N)$, provided a rigorous geometrical derivation of industry supply curves from the firms' cost situations in competitive conditions, and became the springboard for numerous further contributions. In December 1935, the mathematician Karl Menger then severely criticized the axiomatic acceptance of the law of diminishing returns by showing that the existing a priori "proofs" of this alleged "law", put forward by authors such as Böhm-Bawerk, Wicksell, Mises and others, were invalid. Menger was instigated to his contribution by discussions in the $N O e G$ following the presentations of Morgenstern and Viner, and it was Morgenstern also who channeled the resulting (two-partite) paper into the ZfN for publication (see Menger 1936a, b; the two parts were later published together in a revised English translation as Menger 1954 and, in a slightly revised version, as Menger 1979). ${ }^{1}$

The connecting link between the contributions of Morgenstern, Viner, and Menger is their common concern with the role of diminishing returns in the explanation of long-run industry supply curves with increasing costs. Accordingly, the present paper has been organised as follows. Section 2 briefly summarizes Morgenstern's review article, focusing attention in particular on the problems relating to the construction of long-run industry supply curves with rising supply prices. ${ }^{2}$ In Sect. 3, Viner's 1931 article on "Cost curves and supply curves" is re-examined, with the main focus being, again, on the construction of upward-sloping industry supply curves in a partial equilibrium setting. Section 4 then turns to the discussion of Karl Menger's "Remarks on the law of diminishing returns" (1979 [1936a, b]), and Sect. 5 offers some conclusions.

\footnotetext{
1 The Zeitschrift für Nationalökonomie also published several further contributions on the laws of costs and returns; see, e.g., Tinbergen (1930), Schiff (1931), von Stackelberg (1931-32), Liefmann (1932), and Sweezy (1933). Under Morgenstern's editorship, the ZfN quickly established itself as the leading economic theory journal in the German language area.

${ }^{2}$ For a fuller discussion of Morgenstern's paper and its importance for the debates on the laws of costs and returns in the German-speaking countries in the 1930s and 1940s, see Gehrke and Kurz (2010).
} 


\section{Oskar Morgenstern on "Open problems in the theory of costs and returns"}

In an introductory footnote, Morgenstern (1931: 481) notes that his paper closely resembles his $N O e G$ presentation and that the theory of returns had been the topic of a seminar he had taught in the winter term 1929/30 at the University of Vienna, together with Gottfried Haberler and Friedrich Hayek. An entry in Morgenstern's diary reveals that both Haberler and Hayek attended his presentation, which was "well received" and sparked a "very lively discussion". 3 Morgenstern's paper is best described as a review article of the more important contributions to the "cost controversies", with some perceptive comments by himself. However, Morgenstern decided to focus attention mainly on a single contribution to these debates:

One of the most valuable and stimulating works that seems to have been induced by this controversy is an investigation by Piero Sraffa [1925]: Sulle relazioni fra costo e quantità prodotta, with which in the following we shall primarily concern ourselves. Its high quality and the discussions it triggered make it particularly suitable for our endeavour. (Morgenstern 1931: 493)

The entire Part III of Morgenstern's article, which makes up approximately twothirds of the entire text, is in fact devoted exclusively to the discussion of Sraffa's 1925 article, ${ }^{4}$ so that Morgenstern's paper amounts in effect to a critical review article of Sraffa's contribution.

Before we can enter into the discussion of Morgenstern's article it is apposite to draw attention to two features of Marshall's approach which must be clearly recognized for a proper appreciation of the contributions of Sraffa and Morgenstern. The first feature was explained succinctly by Opocher and Steedman (2008), who showed that Marshall's "supply equation" (1920 [1890]: 852) can be conveniently written as $p=\boldsymbol{a}(Q) \cdot \boldsymbol{w}(Q)$, where $p$ denotes the price of a commodity whose aggregate output $Q$ is assumed to be produced by means of a set of inputs whose amounts per unit of product at the bottom of the firm's average cost curve are the terms of the vector $\boldsymbol{a}$, and whose long-run supply prices are the terms of the vector $\boldsymbol{w}$. Both $\boldsymbol{w}$ and $\boldsymbol{a}$ are vector functions of $Q$, so that the sign of the derivative, $d p / d Q$, depends on $\boldsymbol{a} \boldsymbol{w}_{Q}+\boldsymbol{a}_{\boldsymbol{Q}} \boldsymbol{w}$, where $\boldsymbol{w}_{Q}$ and $\boldsymbol{a}_{Q}$ are vectors of derivatives. It is the aggregate effect of the involved changes in both input prices and input quantities which Marshall's industry supply curve was meant to depict:

The supply curve for a certain industry, then, was simply designed to illustrate the outcome of one possible set of market circumstances of supply. Many different factors were at work simultaneously: as the demand for a commodity rises permanently and aggregate production increases, some raw materials are

\footnotetext{
3 See the entries for 11 January and 8 February 1930 in the Oskar Morgenstern diary (OMD). Unless otherwise stated, the English translations from the Oskar Morgenstern diary, as well as those from Morgenstern's article "Offene Probleme der Kosten- und Ertragstheorie" (1931), are mine.

4 In the following, all references to Sraffa's article, originally published in Italian in 1925, are to the English translation in Sraffa (1998 [1925]).
} 
supplied to the industry at an increasing price, some machinery is supplied at a falling price, some kinds of labour are made available at a rising wage, some technological and organisational economies dependent upon the industry's scale are introduced. The slope of the Marshallian long-period supply curve ... reflects all these factors simultaneously. (Opocher and Steedman 2008: 252)

The second important feature to which attention must be drawn concerns the specific factor supply framework in which Marshall was arguing, and which for obvious reasons has been designated as a "Ricardo-Marshall framework". Its peculiarities have been described most succinctly by Joan Robinson, who also provided some hints on its historical origins:

The classical analysis, which gave rise to the Ricardian theory of rent, dealt with the question of what happens when the supplies of labour and capital increase, and land remains fixed. This clearly has nothing to do with rising supply price for a commodity. It belongs to the department of output as a whole. ... The problem of the long-period supply curve of a particular commodity belongs to the department of the theory of value, which treats of relative prices of commodities. Marshall's analysis appears to be a cross between the theory of value and the theory of output as a whole. For he seems most often to be discussing the problem of the change in the supply of a particular commodity which occurs in response to a net increase in demand. The demand for one commodity increases, but the demand for the rest does not decline. The additional factors, apart from land, employed in increasing the supply of the commodity are called into existence by the increase in demand. (Robinson 1941: 233-234; emphases added)

As Freni (2001: 365) has noted, this "was the Marshallian framework commonly employed before the 1930s"; it was also the framework adopted implicitly by Sraffa (1998 [1925]) and Morgenstern (1931). As we shall see below, Jacob Viner, in the first part of his original article of 1931, also adhered to this peculiarity of Marshall's approach, but subsequently abandoned it in favour of a fixed, or alternatively of an imperfectly elastic, factor supply framework. We can now proceed to take a closer look at Morgenstern's paper.

Its main part opens with the statement that in order to arrive at a satisfactory theory of prices it is necessary to re-examine the laws of costs and returns. While it is unproblematic to explain the negative inclination of the demand curve from the principle of marginal utility, "it is not possible to make any a priori statements about the slope of the supply curve" (Morgenstern 1931: 483). According to Morgenstern, it is "pure arbitrariness" to presume an upward-sloping curve, "since there exists no principle whatsoever that corresponds to that of diminishing marginal utility for the demand curve" (1931: 483-484). ${ }^{6}$ This statement might seem surprising, because

\footnotetext{
5 See Freni (2001: 366).

6 According to Morgenstern, in "this field, which seemingly belongs to the most securely established ones of all economic theory, there is one open problem next to the other" (1931: 494).
} 
the received view at the time was, of course, that such a principle exists in the form of the law of diminishing marginal productivity. In fact, according to Marshall (1920: 170n), the case of diminishing marginal productivity is completely analogous to that of diminishing marginal utility: the latter is said to be grounded in the characteristics of human nature, the former in the technical characteristics of industry. For Sraffa, whom Morgenstern followed in this regard, this coincidence is remarkable: "Is it not very strange that two such heterogeneous things as human nature and industrial technology should bring about results so similar?" (1998 [1925]: 332). Sraffa indeed repudiated the view, which had been advanced by economists like John Stuart Mill, Marshall, and Pantaleoni, that the law of diminishing returns is firmly rooted in technical or natural scientific principles: "The facts are otherwise" (1998 [1925]: 333).

What gives rise to diminishing returns is not the characteristics of agricultural technology, but rather the choices of cost-minimizing producers. As Sraffa explained in detail with regard to the choice of technique problem in the presence of land scarcity, it is the farmer who is forced to vary the input proportions because the quantity of land at his disposal cannot be expanded, and who chooses to first apply those methods which yield the greatest product per unit of the variable factor. Moreover, he demonstrated that increasing returns can arise only if the constant factor is indivisible and "exists in an excessive and harmful quantity, and it is not possible to get rid of it without cost" (Sraffa 1998 [1925]: 331). With unlimited divisibility, marginal returns can only be constant or falling; there are no good reasons for assuming S-shaped productivity curves. Diminishing returns or increasing costs therefore arise not from some technical relation or natural law, but from the choices of the producers, who deliberately arrange the doses of the variable factor in a descending order of the corresponding returns ${ }^{7}$ : "This choice is already, in itself, a long way from agricultural technology" (1998 [1925]: 334). If one takes into consideration that the farmer can typically produce different agricultural products on the land, the distance from a purely technical relation becomes even greater, because the heterogeneous products must then first be made commensurable in order to determine the order in which the available methods are applied. A classification of industries into increasing or decreasing cost industries on the basis of their "technical characteristics" is therefore not possible.

In addition, it must be noted that an element of arbitrariness is introduced into the classification of industries through the criterion which is used as the basis of the definition of an "industry":

If every single industry is defined as the exclusive consumer of a given $f a c$ tor of production (for example, agriculture, the iron industry, etc.), a condition

\footnotetext{
7 "The same argument may be repeated for the case of diminishing utility ... which is a special case of diminishing productivity, when we consider utility as product, the commodities consumed as the variable factor of production, and the 'sensitive organism' as the constant factor. It is not any allegedly psychophysical law which endows diminishing utility with generality, but the possibility of using different doses of a commodity to satisfy different needs and the desire to utilise the first doses to satisfy the most urgent needs." (Sraffa 1998 [1925]: 338).
} 
is at once assumed that implies a tendency towards increasing costs for the industry, since it is precisely the factor that is characteristic of the industry (cultivable land, iron mines, etc.) that, with the increase of production, generally remains constant. If, on the contrary, every industry is defined as the sole producer of a given product, and this is meant in a fairly restrictive sense, so that in general it can be thought that every industry uses only a small fraction of each factor of production (negligible in comparison to the quantity used by all the other industries together), we thereby exclude from the industry the circumstance that generates increasing costs and make it more probably subject to the law of constant costs, or, in further specific conditions, to the law of decreasing costs. (1998 [1925]: 357)

In order to be employed in the analysis of a "particular equilibrium", an industry supply curve must satisfy the following conditions: ( $i$ ) it must be independent of both the corresponding demand curve and of the supply curves of other commodities; (ii) it is valid only for small variations in the quantity produced, since a large variation would, in general, be incompatible with the ceteris paribus clause. As Morgenstern notes, Sraffa then demonstrated that:

These conditions reduce to a minimum the range over which hypotheses of increasing costs are applicable to the supply curve of a product. They are satisfied only in those exceptional cases where the totality of a factor is used in the production of a single commodity. (1998 [1925]: 359)

If this is not the case, and a factor is used by a number of industries producing different products, the above conditions for a partial equilibrium analysis are violated. If the number of those industries is small, condition $(i)$ would be violated: If a certain type of land, for instance, is used in the production of apples and pears, then an increase in the rent of land that is caused by a variation in the produced quantities of apples would raise not only the costs in the apple industry, but those of the producers in pears industry as well. In the contrary case, in which the number of industries using a common factor is large (so that each industry is using only a small amount of it), an appreciable effect on the price of this factor (and thus on the costs of the expanding industry) could emanate only from a large variation of output-which would be contrary to the second condition. To conclude, whenever the industry's costs are affected by the output variation, a partial equilibrium analysis is impossible; a general equilibrium analysis is required. It would at any rate be inadmissible that the equal effects of a single cause are at the same time considered to be negligible in the one case, and of fundamental importance in the other: "However, it is necessary to accept this absurdity, if one wishes to give a general, and not an anomalous character, to the supply curve of a product under conditions of increasing costs." (1998 [1925]: 360)

Morgenstern fully endorsed Sraffa's argument. With regard to first increasing and then decreasing returns in the presence of a constant factor he observed, following Sraffa, that this implicitly presupposes the existence of indivisibilities. He also agreed with Sraffa's conclusion that diminishing returns are not resulting from some physical necessity but from the cost-minimizing behaviour of the 
producers (1931: 501). And he stressed that with Sraffa's finding that in the case of the joint use of a constant factor by several, but few industries the costs of all of them tend to rise when the output of one of them is expanded, "the method of partial equilibrium is already demolished" (Morgenstern 1931: 520). Finally, Morgenstern also shared Sraffa's objections to the received way of constructing an industry supply curve by means of adding up the supply curves of individual firms. In particular, he noted that

In order to be able to make a summation of [the firm supply curves], specific assumptions need to be introduced: the number of firms must be assumed as given and constant, and the amount of the 'constant factor' used by each one of them must be conceived as rigidly fixed. (1931: 503)

To this Morgenstern added the further remark:

Thus far Sraffa, with whom one will have to concur in this argumentation. But one will also have to observe that these two additional assumptions make the statements about diminishing returns appear even more contrived than they already are. ... Since the law of diminishing returns, as compared to the still unexplored one of increasing returns, has generally been regarded as simple and well-established, one can look forward only with trepidation to the problems that stand in the way of an explanation of the supply curve with decreasing costs. (1931: 503)

With regard to the derivation of industry supply curves with decreasing costs, Morgenstern also essentially agreed with Sraffa's argument. According to Sraffa, decreasing average costs of a firm with increasing levels of output can emerge from two different causes. The first one relates to the fact that with an increased size of the firm it gains access to more efficient production methods, that is, there are "internal economies (of scale)". This case differs fundamentally from the case discussed above, where because of the indivisibility of some particular factor the productivity of some other factors increases over a certain range of the output expansion. In the latter case the result derives from a change in the factor input proportions, whereas in the former case it is caused by a change in the quantities of the total complex of factors, whose input proportions may (but need not) remain constant. Economies of the first type give rise to decreasing marginal costs, which in turn generate decreasing average costs. The second cause of decreasing costs relates to the fact that every firm operates with some "overheads", which are independent of the output (or increase less than proportionally with the output). In this case, marginal costs are constant (or almost constant); it is average costs alone that are decreasing. However, as already noted by Marshall, the case of firm-internal decreasing costs (increasing returns) falls outside of the scope of the theory of prices under competitive conditions, because it must inevitably lead to industry concentration or monopoly. On the other hand, "economies of scale" that affect the entire economic system, such as Adam Smith's "increasing division of labour", are incompatible with a partial equilibrium analysis. Thus, in order to accommodate increasing returns in a theory of competitive 
prices in a partial equilibrium framework it must be assumed that the economies of large-scale production under consideration are external to the firm and internal to the industry. However, in Sraffa's view such economies are seldom to be met with, and the examples proffered by Marshall as "empirical illustrations" are unconvincing: “'External economies' peculiar to an industry, which make possible the desired conciliation between scientific abstraction and reality, are themselves a purely theoretical and unreal construction." (1998 [1925]: 347) Industry supply curves with decreasing costs which emanate from internal or external economies therefore cannot be accommodated, for different reasons, in a partial equilibrium analysis of competitive prices.

In view of these findings, and given the highly problematic assumptions that had to be introduced for the construction of supply curves for increasing cost industries, summarised above, Sraffa concluded:

There are then strong reasons ... why, apart from exceptional cases, non-proportional cost curves cannot be involved in the determination of the particular equilibria of single commodities in a static system of free competition, without assumptions being introduced that contradict the nature of the system. (Sraffa 1998 [1925]: 363)

Morgenstern immediately realised, and explicitly spelled out, the destructive power of Sraffa's findings for a competitive price theory based on the symmetry of supply and demand in a partial equilibrium framework:

For the construction of the curve of rising supply prices similarly artificial assumptions had to be made as for the curve of decreasing supply prices, which at any rate is conceived by many merely as a historical curve. ${ }^{8}$ These facts are most embarrassing because of the price theory. (Morgenstern 1931: 517; emphasis added $)^{9}$

Morgenstern deplored the fact "that the conclusions Sraffa derived from his findings for the price theory have, to the best of my knowledge, not received any attention" (1931: 518), although the gist of his argument had been made available also in English (cf. Sraffa 1926). One of Sraffa's conclusions was that, as a first approximation, constant costs could be supposed to prevail. On this Morgenstern remarked:

Whether, as Sraffa contends, so little attention has been given to constant costs, because their prevalence disturbs the symmetry of supply and demand (in Marshall) - and one should add: threatens the primacy of demand (in the Austrians) - can be left for further consideration. But a motive would have been found. (Morgenstern 1931: 518).

\footnotetext{
${ }^{8}$ This refers to the criticism of Marshallian decreasing cost curves by Allyn Young (1928), which Morgenstern summarised approvingly (1931: 514-516).

9 The italicized passage reads in the German original: "Diese Umstände sind wegen der Preistheorie überaus peinlich.” (Morgenstern 1931: 517).
} 


\section{Viner's article on "Cost curves and supply curves"}

Jacob Viner's 1931 article, the concepts and ideas he introduced, and in particular the graphical techniques he employed, had a major impact on the further development of microeconomic theory. Viner distinguished between different cost situations, for the firm and the industry, in the short and in the long run, and derived the corresponding supply curves in each case. He analysed the relationship between marginal and average costs, the role of external and internal economies, and introduced the distinction between pecuniary and technological external economies and diseconomies (Viner 1953 [1931]: 213-222)—a distinction which in Marshall had been only implicit. Most importantly in the present context, he also examined the case of what he called "Ricardian" increasing costs based on the assumption of industry-specific factors (later, in its application to international trade theory, this has been called the "Ricardo-Viner" or "Specific factor" model). ${ }^{10}$

In his 1931 paper, Viner was not very clear on how his analysis of cost and supply curves was supposed to relate to the methods of partial and general equilibrium analysis. While he explicitly saw his paper as a contribution to partial equilibrium analysis, "based on the usual assumptions and presuppositions of the Marshallian type of economics", he also asserted that the errors in results obtained, as compared to "the Lausanne School type of analysis, ... will be almost invariably quantitative rather than qualitative in character, and will generally be even quantitatively of minor importance" (1953 [1931]: 199-200). It was only later, in a "Supplementary Note" added in 1950, that Viner repudiated this view and stressed the much greater relevance of pecuniary diseconomies of large-scale production in a general equilibrium setting — without, however, acknowledging explicitly the associated irrelevance of such diseconomies in a partial equilibrium setting.

In the following, we focus attention exclusively on Viner's contribution to the construction of long-run industry supply curves with increasing costs, ${ }^{11}$ for which he proposed two different explanations: "Ricardian" increasing costs and (pecuniary) diseconomies of scale. Let us take a closer look at each of the two in turn.

"Ricardian" increasing costs. The first explanation refers to "the case usually designated in textbooks as the case of "increasing costs"' (1953 [1931]: 209). According to Viner, it is "a special case corresponding to the Ricardian rent theory in its strictest form" (1953 [1931]: 206), because it is assumed that "a given industry [agriculture] is already utilizing all of the supply available at any price of a necessary factor of production [land], so that the output of the industry as a whole can be increased only by the more intensive utilization of the absolutely limited factor"

\footnotetext{
10 Viner's article became well-known also for the famous error of instructing his draftsman, Mr. Wong, to draw the long-run average cost curve as passing through the minimum points of the short-run average cost curves, instead of drawing it as the envelope of the short-run average cost curves.

11 For a critical discussion of Viner's analysis of decreasing costs based on "external economies" and its impact on subsequent developments in partial and general equilibrium price theory, see Gehrke (2015). It may here be noted, however, that Viner (1953 [1931]: 217) also dismissed Marshall's concept of "technological external economies" as a purely theoretical construction, for which it is difficult to find any empirical illustrations.
} 
(1953 [1931]: 206-207). Since this factor is supposed to be a specific factor that is used only in this particular industry, the increase in its price (i.e. in land rent) resulting from its more intensive use affects only the cost situations of the firms operating in this industry. However, as Viner rightly pointed out, "long-run average costs rise even if the increase of rent is disregarded", because the intensification of land cultivation implies that "there are increasing unit technological costs" (1953 [1931]: 209). Therefore, irrespective of "whether the technical coefficients are weighted by the original or by the new prices of the factors", there must always be "increasing long-run average costs as well as increasing marginal costs" (1953 [1931]: 209). Viner thus demonstrated how a long-run partial equilibrium industry supply curve with increasing costs can be consistently derived from the presence of an industryspecific factor in limited supply. He omitted to engage, however, with Sraffa's argument, fully endorsed also by Morgenstern, that empirically the cases are rare in which an industry is (or can be defined as) the exclusive user of a limited factor (see the apples-and-pears example referred to above).

(Pecuniary) diseconomies of scale. Viner's second explanation for increasing cost industries refers to "net diseconomies of large production". But whereas he discussed at some length the case of net internal economies of large-scale production, and in this context presented the famous chart with the downward-sloping long-run average cost curve of the firm drawn incorrectly (see chart IV in Viner 1953 [1931]: $215)$, Viner refrained from providing a graphical illustration of net internal diseconomies of large production, because "this case has no practical importance" (1953 [1931]: 217). He motivated this statement by invoking the replication argument: "It will always be possible for the industry as a whole to avoid the net internal diseconomies of large-scale production by increasing its output through increase in the number of plants without increase in their scale." (1953 [1931]: 217) Consequently, Viner also refrained from drawing a U-shaped long-run average cost curve for the firm. With firm-internal diseconomies ruled out, we are left only with the case of net external diseconomies of large production, which nowadays serves as the standard explanation of rising industry supply curves. Notably, it was introduced by Viner with the remark that it had previously received scarcely any attention:

Although it has not ordinarily been given consideration, ${ }^{12}$ the case of net external diseconomies of large production is of indisputable practical importance. Pecuniary diseconomies of this kind will always tend to result from the expansion of output of an industry because the increased purchases of primary factors and materials which this entails must tend to raise their unit prices. (1953 [1931]: 220; emphasis added)

While in his explication of "Ricardian" increasing costs Viner had still argued in a "Ricardo-Marshall" framework, he now introduced a fixed (or imperfectly elastic) factor supply framework. Moreover, the novel factor supply assumptions, which concern only primary factors of production like land and labour, were

\footnotetext{
12 This would seem to confirm our statement in Sect. 2 above that prior to Viner the factor supply framework adopted in partial equilibrium analysis was the "Ricardo-Marshall framework".
} 
compounded by him with considerations regarding the supply of "materials" by other industries:

In order that pecuniary diseconomies shall not result from the expansion of an industry's output, it is necessary, for both primary factors of production and materials, that the increase in demand by this industry shall be accompanied by a corresponding and simultaneous decrease in demand by other industries or increase in the supply of the factors and materials themselves, or failing this, that the materials, because of net external and internal economies in the industries producing them, should have negatively inclined supply curves. (1953 [1931]: 220)

As before, Viner here also refrained from engaging with Sraffa's argument, fully endorsed also by Morgenstern, that such pecuniary diseconomies cannot be taken into consideration in a partial equilibrium analysis. With regard to primary factors like land and labour, a partial equilibrium analysis requires the limited factor to be industry-specific. And with regard to materials supplied by other industries Sraffa's argument remains valid, according to which small changes in output cannot cause appreciable changes in input prices, whereas large changes are incompatible with the method of partial equilibrium. Accordingly, and contrary to Viner's assertions, pecuniary external diseconomies of large-scale production are difficult to accommodate in a partial equilibrium setting. On the other hand, however, Viner explicitly dismissed Marshall's concept of technological external diseconomies of large-scale production as a purely theoretical construction, for which it is difficult to find any empirical examples:

External technological diseconomies, or increasing technical coefficients of production as output of the industry as a whole is increased, can be theoretically conceived, but it is hard to find convincing illustrations. One possible source might be higher unit highway transportation costs when an industry which provides its own transportation for materials and products expands its output and thereby brings about traffic congestion on the roads. (1953 [1931]: 221)

For Viner there remain, then, only pecuniary diseconomies-which, however, as Sraffa and Morgenstern noted, are incompatible with a partial equilibrium analysis. On the other hand, Viner did point out, unlike Sraffa and Morgenstern, that "these pecuniary diseconomies ... may be more than counterbalanced by technological external economies, and need not necessarily result, therefore, in net external diseconomies" (1953 [1931]: 220-221; emphasis added). With "Ricardian" increasing costs resulting only in "special cases", and with the net effect on the slope of the industry supply curve in the presence of both (pecuniary) diseconomies and (technological) economies of large-scale production being highly uncertain, there are, then, no good reasons for presuming that partial equilibrium industry supply curves must typically exhibit increasing costs. Viner did not specifically emphasize this conclusion, but it is clearly implied by his analysis. 
In a Supplementary note (1953 [1950]), first published in 1950, Viner "corrected" his previous exposition of the construction of long-period industry supply curves, leaving a wider scope for the prevalence of net external diseconomies, and thus for the possibility of upward-sloping industry supply curves, than had been the case in his previous analysis:

I feel it incumbent upon me ..., so as to avoid propagating serious error, to carry the analysis of costs a stage further in one respect by departing here from the traditional Marshallian pattern of assumptions to which the article adheres. The partial-equilibrium nature of the Marshallian assumptions leaves a wider range of possibilities to the long-run tendency of costs for an expanding industry than is consistent with general-equilibrium analysis. (1953 [1950]: 227; emphasis added)

Contrary to Viner's assertion, however, the main difference between his earlier and his new analysis is not that the former "adheres", and the latter does not adhere, to "the partial-equilibrium nature" of Marshall's assumptions - it rather lies in the introduction of different assumptions with regard to factor supplies. Viner now assumed explicitly that all factors are in fixed supply, ${ }^{13}$ so that an expanding industry can use larger amounts of factors only if the latter are released by other industries, whose output must accordingly be contracting. But since the various factors are in general not released in the exact proportions in which they are needed by the expanding industry, there will have to be a change in relative input prices 'whose necessary effect will be to raise the supply price of the commodity in question relative to "other" commodities (as well as to economise the relatively scarce factor)' (Opocher and Steedman 2008: 261). Viner accordingly concluded that "all industries must tend to be subject to 'external net pecuniary diseconomies of large production' when they expand relative to the economy of which they are a part" (1953 [1950]: 228; emphases added).

\section{Karl Menger's "Remarks on the law of diminishing returns"}

Another "excellent paper" 14 on the laws of costs and returns that was first presented at a NOeG meeting ${ }^{15}$ was a contribution by the mathematician Karl Menger (1979). In this paper, originally published in German in two parts (Menger 1936a, b), Menger scrutinizes "logical deductions" or "a priori proofs" of the law of diminishing returns that can be found in the economic literature and shows them to contain errors of reasoning. In addition, Menger also demonstrates the general impossibility

\footnotetext{
13 In a subsequent part of his "Supplementary Note" Viner then allowed also for imperfectly elastic factor supplies, and argued that the effects on the supply curve of the industry under consideration "are the same in direction ... but less in degree" (1953 [1950]: 230).

14 Stigler (1968 [1941]: 49).

15 Menger presented this paper at a NOeG meeting on 30 December 1935.
} 
of a logical proof of the law of diminishing marginal returns from the set of assumptions that had been typically invoked by economic theorists.

In an introductory footnote, Menger points out that he was induced to the writing of his paper by "the interesting article of O. Morgenstern (1931)", by "discussions in the Viennese Nationalökonomische Gesellschaft", and by "a conversation with Prof. L. v. Mises" (1936a: 25). Menger further specified this remark in a prefatory note to the English version of his paper:

This paper goes back to a conversation about the methodology of economics in which L. Mises claimed that certain propositions of economics can be proved. As an example, he mentioned the law of diminishing returns and referred me to the literature for the proofs. After I presented my findings to the Viennese Economic Society ... Mises wrote me that he learned a great deal from the paper. (1979: 279)

Oskar Morgenstern, in a diary entry of 31 December 1935, provided the following account of this meeting:

Yesterday ... Menger gave a brilliant paper on the law of diminishing returns. It was an exemplary performance for showing the need for exact reasoning in economics. Interestingly, Haberler completely failed in the discussion; I very much noticed this. Of all these exact things he still does not understand the essence. Mises uttered pure nonsense. ${ }^{16}$ (Entry in Oskar Morgenstern Diary, 31 December 1935)

Menger's paper opens with some methodological remarks, in which he explains his own understanding of the meaning of his findings: "By saying that a proposition does not follow from certain assertions, we do not mean that it is not valid. ... Conversely, by saying that a proposition follows from certain others, we do not mean that it is valid. Even if a scientific proposition can be correctly derived from generally accepted propositions only experience can show whether or not the derived proposition is valid." (1979: 280; emphasis added). In Menger's understanding, "the crucial issue for economics [is] whether or not these laws are empirically confirmable" (1979: 280). "Whether or not they follow from certain other propositions" is, in Menger's view, an issue that in itself is not of much interest: "It is, rather, some outstanding economists who have raised this issue by claiming to prove the law of diminishing returns on land logically, and thereby to make empirical tests superfluous. All that we here say is that logical relationships, equivalences, deductions, proofs, etc. must be handled correctly" (1979: 280).

In the main section of his paper Menger then first shows that in their formulations of the law of diminishing returns many economists did not properly specify the

\footnotetext{
16 „Gestern war nat.ökon. Gesellschaft: Menger hielt einen glänzenden Vortrag über das Gesetz v. abnehmenden Ertrag. Es war eine mustergültige Leistung für den Nachweis der Notwendigkeit des exakten Denkens in der Ökonomie. Interessant war, daß Haberler in der Diskussion gänzlich versagte; mir ist das sehr aufgefallen. Von allen diesen exakten Dingen versteht er noch lange nicht das wesentlichste. Mises redete reinen Unsinn zusammen“.
} 
premises and concepts underlying their analysis, and in particular did not properly distinguish between marginal and average returns. ${ }^{17} \mathrm{He}$ then provides a rigorous mathematical definition of the "classical" law of diminishing returns by means of various mathematical concepts like additivity and homogeneity (1979: 280-292). After these preliminaries, Menger then shows that various lines of argumentation, which have been presented in the economic literature as a priori proofs of the law of diminishing returns on land (and which are sometimes presented as such even today), either make use of incorrect deductions in the chains of reasoning or contain logical errors. After showing the so-called "flower-pot argument" to be invalid, ${ }^{18}$ Menger scrutinizes the alternative "proofs" offered by Mises (1933: 45-46), BöhmBawerk (1924 [1912]: 193-198), and Wicksell (1909a: 354-355), and shows all of them to be inconclusive as well. As an example, let us consider his treatment of Wicksell's argument. With regard to the law of diminishing returns from land the latter had asserted:

The validity of the law of returns on land does not require experimental proof, but presents itself as a logical postulate or corollary. For if it could be shown that twice the labor and twice the capital applied to a piece of land would yield twice the product, an even better result would be achieved per unit of capital and labor if the labor and capital at hand were concentrated on half of the formerly used area, the remainder to be used for grazing, forestry, or some other productive purpose which requires no labor. (Wicksell 1909a: 354-355; emphasis in the original)

This argument was repeated also in Wicksell's Lectures (1934 [1901]: 122-124), and a similar "proof" was presented algebraically as well ${ }^{19}$ :

Apply $A$ labor to $B$ land, securing $P$ product. Then $\frac{A}{2}$ plus $\frac{B}{2}$ will yield $\frac{P}{2}+\frac{p}{2}$, where $\frac{p}{2}$ is the natural product of the now uncultivated half of the land. Then $\frac{P}{A} / \frac{\frac{P}{2}+\frac{p}{2}}{\frac{A}{2}}=\frac{P}{P+p}<1$. (Wicksell 1909b: 569)

Wicksell concluded from this result that the law of diminishing returns is not an empirical rule, but "a theorem of mathematical necessity" (1909b: 569). As Menger points out, Wicksell's "proof" assumes that the production function is sub-homogeneous and super-additive, and that land is an independent input (i.e. yields a product even without the use of any cooperating input). Given these assumptions, it is easily proved, as Menger (1979: 296) shows, that decreasing average returns must prevail, but not necessarily decreasing marginal returns (which, of course, is the economically significant property). In the following, Menger then not only shows that the

\footnotetext{
17 This was previously pointed out also by Edgeworth (1925).

18 This argument states that if the law of diminishing returns were not valid, then all the agricultural products needed by the entire population of a country could be produced on a small area of land (i.e. "in a flower-pot"). As everyone knows, this is not the case. Hence, the law of diminishing returns on land cannot be false; that is, it must hold. As Menger (1979: 293) shows, this inference is wrong, because the assumption of the boundedness of the production function implies neither diminishing product increments nor diminishing average products.

19 Wicksell had studied mathematics and physics before he became an economist.
} 
logical deductions proposed by Böhm-Bawerk and Mises are flawed as well, but also demonstrates the general impossibility of a logical proof from the set of assumptions that have typically been invoked by economic theorists.

For almost three decades, Menger's important paper appears to have been unduly neglected. ${ }^{20}$ It was only after its publication in English, in a compilation of contributions to mathematical economics edited by Oskar Morgenstern in 1954, that some mathematical economists set out to provide rigorous proofs of the law of diminishing returns by introducing appropriate restrictions on technology. ${ }^{21}$ Thus Ronald W. Shepard demonstrated that the law can be proved when the production function is assumed to be homogeneous of degree one and the input sets are supposed to be strictly convex for positive output (properties which are possessed by Cobb-Douglas and $C E S$ production functions). Interestingly, he stressed the tautological character of his exercise by introducing his proofs with the remark that "the traditional forms of the law cannot be obtained without assumptions on the fine structure of a technology which are contrived to obtain the result" (Shepard 1970: 9; emphasis added).

To conclude, Menger in his 1936 paper severely criticized the axiomatic acceptance of the law of diminishing returns by economic theorists. By demonstrating that the existing a priori proofs were invalid, he showed that the law is not "a theorem of mathematical necessity" and does not follow logically from accepted premises of economic theory, as some major economic theorists in the Austrian tradition had asserted. Accordingly, his call "for direct empirical verification of the law ... remains valid" (Brue 1993: 189).

\section{Conclusions}

Contrary to the views of eminent economic theorists of the late nineteenth and early twentieth century, the law of diminishing (marginal) returns is neither implied by the "technological characteristics of industry", as Oskar Morgenstern (1931), following Sraffa (1998 [1925]), realized, nor is it a "theorem of mathematical necessity", as Karl Menger (1979 [1936a, b]) clearly demonstrated. Diminishing marginal returns rather derive from the deliberate choices of cost-minimizing producers among the technical alternatives available to them, when the amounts of some inputs cannot be expanded proportionately. In order to derive long-run industry supply curves with increasing costs in a partial equilibrium setting the existence of an industry-specific factor in limited supply and/or firm-external diseconomies of large-scale production must be assumed to prevail, as Jacob Viner (1953 [1931]) has shown. However, empirical illustrations for these theoretical constructions that meet the conditions which must be fulfilled in order to render an analysis in a partial equilibrium setting possible are difficult to find. Modern microeconomics textbooks often do not sufficiently emphasize the limited scope for partial equilibrium long-run industry supply curves with increasing costs.

\footnotetext{
20 See, however, Stigler (1968 [1941]: 49 and 266-267) and Schumpeter (1954: 1037).

21 See Eichhorn (1968), Shepard (1970), and Färe (1980).
} 
In standard textbooks, the assumption of an industry-specific factor is typically mentioned in explaining the construction of a long-run industry supply curve with increasing costs, but it is not made clear that whether or not a factor can be conceived as industry-specific depends crucially on the definition of an industry. Moreover, the "Ricardian increasing costs" or "specific factor" case is not properly distinguished from, and indeed often confounded with, the "pecuniary diseconomies of scale" explanation for rising supply prices. As an example, consider the following passage from a widely used textbook in undergraduate education:

In an increasing-cost industry the prices of some or all inputs to production increase as the industry expands and the demand for the inputs grows. Diseconomies of scale in the production of one or more inputs may be the explanation. Suppose, for example, that the industry uses skilled labor, which becomes in short supply as the demand for it increases. Or, if a firm requires mineral resources that are available only on certain types of land, the cost of land as an input increases with output. (Pindyck/Rubinfeld 2013: 308)

Different explanatory elements are indiscriminately lumped together here: In order to explain an upward-sloping long-run industry supply curve diseconomies of scale in some supplying industries are invoked, together with the presence of specific factors (in the supplying industries?) which are in limited supply. This explanation gives the impression of providing a good empirical illustration of an increasing-cost industry, but its (in)compatibility with a partial equilibrium analysis is not explained. Moreover, no motivation is offered for the fact that in the subsequent chapter of this textbook, which is devoted to "The analysis of competitive markets" (Pindyck/Rubinfeld 2013: 317-354), long-run industry supply curves are generally taken to exhibit increasing costs, thus relegating to the status of exceptional/special cases industry supply curves with constant or decreasing costs.

Acknowledgements Open access funding provided by University of Graz.

Open Access This article is distributed under the terms of the Creative Commons Attribution 4.0 International License (http://creativecommons.org/licenses/by/4.0/), which permits unrestricted use, distribution, and reproduction in any medium, provided you give appropriate credit to the original author(s) and the source, provide a link to the Creative Commons license, and indicate if changes were made.

\section{References}

Böhm-Bawerk E von (1924 [1912]) Einige nicht neue Bemerkungen über eine alte Frage. In: Gesammelte Schriften, vol 1. Hölder-Pichler-Tempsky, Vienna

Brue SL (1993) Retrospectives: the law of diminishing returns. J Econ Perspect 7(3):185-192

Edgeworth FY (1925 [1911, 1913]) The laws of increasing and diminishing returns. In: Papers relating to political economy, vol 1, pp 61-99. Originally published as: Contributions to the Theory of Railway Rates. Econ J 21(1911): 551-571, 23 (1913): 346-370

Eichhorn W (1968) Deduktion der Ertragsgesetze aus Prämissen. Zeitschrift für Nationalökonomie 28:191-205

Färe R (1980) Laws of diminishing returns. Springer, Berlin

Freni G (2001) Sraffa's early contribution to competitive price theory. Eur J Hist Econ Thought 8(3):363-390 
Gehrke C (2015) Formalizing "External Economies": Viner, Chipman, and Krugman. Oeconomia $5(3): 331-362$

Gehrke C, Kurz HD (2010) Die Debatte um die Ertrags- und Kostentheorie und ihre Reflexion im deutschen Schrifttum der dreißiger und vierziger Jahre des 20. Jahrhunderts. In: Kurz HD (ed) Wechselseitige Einflüsse zwischen dem deutschen wirtschaftswissen-schaftlichen Denken und dem anderer europäischer Sprachräume. Studien zur Entwicklung der ökonomischen Theorie XXIV, Schriften des Vereins für Socialpolitik, Band 115/XXIV, Duncker \& Humblot, Berlin

Liefmann R (1932) Zur Diskussion über die Kosten- und Ertragstheorie. Zeitschrift für Nationalökonomie 3:368-383

Marshall A (1920) Principles of economics. Macmillan, London

Menger K (1936a) Bemerkungen zu den Ertragsgesetzen. Zeitschrift für Nationalökonomie 7:25-56

Menger K (1936b) Weitere Bemerkungen zu den Ertragsgesetzen. Zeitschrift für Nationalökonomie 7:388-397

Menger K (1954) The logic of the law of return: a study in meta-economics. In: Morgenstern O (ed) Economic activity analysis. Wiley, New York

Menger K (1979 [1936a, b]) Remarks on the law of diminishing returns: a study in meta-economics. In: Selected papers in logic and foundations, didactics, economics. Vienna Circle Collection, vol 10. Springer, Dordrecht

Mises L (1933) Grundprobleme der Nationalökonomie. Gustav Fischer, Jena

Morgenstern O (1931) Offene Probleme der Kosten- und Ertragstheorie. Zeitschrift für Nationalökonomie 2:481-522

Opocher A, Steedman I (2008) The industry supply curve: two different traditions. Eur J Hist Econ Thought 15:247-274

Pindyck RS, Rubinfeld DL (2013) Microeconomics, 8th edn. Pearson, Boston

Robinson JV (1941) Rising supply price. Economica 8:1-8

Schiff E (1931) Ertragsgesetz und industrielle Kostenverrechnung. Zeitschrift für Nationalökonomie 2:418-428

Schumpeter JA (1954) History of economic analysis. Oxford University Press, Oxford

Shepard RW (1970) Proof of the law of diminishing returns. Zeitschrift für Nationalökonomie $30(1-2): 7-34$

Sraffa P (1925) Sulle relazioni fra costo e quantità prodotta. Annali di Economia 2:277-328

Sraffa P (1998 [1925]) On the relations between cost and quantity produced. English translation of Sraffa P (1925). In: Pasinetti LL (ed) Italian Economic Papers, vol 3. il Mulino, Bologna and Oxford University Press, Oxford

Stigler GJ (1968 [1941]) Production and distribution theories. The formative period. Agathon Press, New York

Sweezy AR (1933) Theoretische und statistische Kostenkurven. Zeitschrift für Nationalökonomie 4:515-520

Tinbergen J (1930) Bestimmung und Deutung von Angebotskurven. Ein Beispiel. Zeitschrift für Nationalökonomie 1:669-679

Viner J (1953 [1931]) Cost curves and supply curves. Zeitschrift für Nationalökonomie, 1: $23-46$. Reprinted in Stigler GJ, Boulding KE (eds) Readings in price theory. Allen \& Unwin, London

Viner J (1953 [1950]) Supplementary Note (1950). In: Clemence RV (ed) Readings in economic analysis, vol 2, 31-35. Addison-Wesley, Cambridge. Reprinted in Stigler GJ, Boulding KE (eds) Readings in price theory. Allen \& Unwin, London

Stackelberg H von (1931-32) Grundlagen einer reinen Kostentheorie. Zeitschrift für Nationalökonomie, 3:333-367 and 552-590

Wicksell K (1909a) Über einige Fehlerquellen bei Verifikation des Bodengesetzes, Thünen Archiv II, 347-355

Wicksell K (1909b) Noch einiges über die Verifikation des Bodengesetzes, Thünen Archiv II, 568-577

Wicksell K (1934 [1901]) Lectures on political economy, vol 1. George Routledge and Sons, London. English transl. of Wicksell K (1901) Föreläsingra i Nationalekonomi, vol. 1. Berlingska Boktrycheriet, Lund

Publisher's Note Springer Nature remains neutral with regard to jurisdictional claims in published maps and institutional affiliations. 